\title{
Dying Traditional Water Bodies in India Struggling to Survive against Unplanned Development
}

\author{
Rudresh Sugam, Bhawna Gupta, Diticha Deka \\ Council on Energy, Environment and Water, New Delhi, India \\ Email: rudreshsugam@gmail.com
}

How to cite this paper: Sugam, R., Gupta, B. and Deka, D. (2018) Dying Traditional Water Bodies in India Struggling to Survive against Unplanned Development. Journal of Water Resource and Protection, 10, 539-558.

https://doi.org/10.4236/jwarp.2018.106030

Received: September 8, 2017

Accepted: June 23, 2018

Published: June 26, 2018

Copyright (c) 2018 by authors and Scientific Research Publishing Inc. This work is licensed under the Creative Commons Attribution International License (CC BY 4.0).

http://creativecommons.org/licenses/by/4.0/

\begin{abstract}
India is endowed with diverse and distinctive traditional water bodies. They support large human population and biodiversity but are under continuous stress, caused primarily by demographic pressure and unplanned growth. There has been a decline in their water quality and quantity and several of them have vanished, thanks to improper monitoring of these water bodies. This research study was conducted in Meerut district to help government in identifying status of traditional water bodies and suggest steps necessary for protection of these water bodies. Similar research framework, with minor customization, could be applied to any other district in India. Meerut district, with a population of around 3.5 million people is in an abysmal state as the rivers and groundwater are highly polluted. The last resort-the traditional water bodies are also getting transformed into sewage ponds. A field based research was undertaken - which involved on-ground survey using GPS, GIS mapping \& water quality testing of 120 ponds, distributed across 12 blocks of Meerut district to acquire a practical understanding of the status of these water bodies. The research team also did an informal discussion with around 500 residents, located nearby ponds, to understand the water situation of the locality. Results show that more than $50 \%$ of water bodies are severely polluted (with D.O below $5 \mathrm{mg} / \mathrm{l}$ ) and total dissolved solids (more than $100 \mathrm{NTU}$ ). Fecal contamination was observed in all the ponds that were analyzed. The major problems are excessive nutrient pollution, leading to eutrophication, and sewage contamination. The spatial analysis finds out that around half the ponds have reduced in area. With around 100 upcoming cities in India and most of the cities already experiencing water scarcity, it is essential to digitize, monitor, control \& prevent pollution and most essentially make the people and grassroots institutions aware in order to protect these essential water bodies from getting extinct.
\end{abstract}




\section{Keywords}

Resources Protection, Traditional Water Bodies, Urbanization, GIS, Water Quality, Water Security

\section{Introduction}

India, predominantly characterized by a unique and idiosyncratic geographic variability is endowed with vast reserves of finite natural resources including some very diverse \& distinctive traditional water bodies. These are called Ponds, Tanks, Lakes, Vayalgam, Ahars, Bawdis, Talab, etc. in different parts of the country. These could be broadly categorized under wetlands, which are highly productive ecosystems besides being a rich repository of biodiversity, and are known to play a significant role in carbon sequestration [1]. India is home to about 757,060 wetlands occupying an area of 15.3 million hectare and accounting for approximately $4.7 \%$ of the total geographical area of the country [2]. However, these water bodies are under continuous \& unrelenting stress, caused primarily by demographic pressure and economic growth [3]. The decline in both the quality and quantity of these wetlands in last few decades is to the extent that their potential to render various economic \& environmental services has reduced drastically [4]. The focus of government on building dams and canals, shift of water management from community to government and lack of sewage systems have been the three major causes of degradation of these water bodies [5]. All this is leading to decreased resilience against climate change, especially in regards to water security.

This research study tries to delve deeper into answering following questions:

1) What is the status of traditional water bodies in small cities and towns of India, taking Meerut as a case study, which has a mix of rural and urban culture?

2) In terms of absolute area, at what rate have they declined in the last decade?

3) What have been the reasons for degrading status of these bodies?

4) Why communities who used to worship these ponds are no more protecting these?

5) Are the regulations inadequate? If no, who could be the key stakeholders for implementing these regulations?

6) What could be the essential policy measures to preserve these vital water bodies?

Meerut was chosen as a case study as: it resembles any other tier II city and town in India; it is following similar growth pattern that Indian mega cities did; it has a large number of traditional water bodies; on-ground support of local NGO; support from local administration to carry out the study.

Meerut district, due to improper management of its water resources, is facing extreme water related challenges. The Kali River which flows through the district 
does not contribute to the water supply due to its poor water quality. It has been detected with the presence of heavy metals and other toxic pollutants induced by several polluting industries. In addition to the urban household waste, several industries located on its bank are discharging untreated wastewater directly into the river. The worsening condition can be understood by the fact that the once seasonal river carrying freshwater has transformed now into a perennial river carrying huge amount of sewage and effluents [6]. Groundwater, on which the large proportion of population is dependent for drinking water, is found to be unfit for drinking at many locations in the Meerut city, due to biological, chemical and heavy metal contamination and with TDS levels $314-942 \mathrm{mg} / \mathrm{l}$ in 2011 [7]. People are suffering from cancer, deformities, hepatitis and several other grave diseases after consuming the contaminated groundwater in the region [8].

This research work was undertaken to analyze the status of traditional water bodies as other water sources have been severely polluted. A field based research was undertaken which involved on-ground survey using GPS, GIS mapping \& water quality testing of randomly selected 120 ponds, distributed across 12 blocks of Meerut district to acquire a practical understanding of the status of these water bodies. Also, nearby residents were interviewed to understand their perception about the declining status of traditional water bodies.

This paper has been divided into five sections: Section 1 is introduction, which provides the research context; Section 2 gives a brief background of wetlands importance; Section 3 discusses their aerial extent in India and the major reasons behind their deteriorating status; Section 4 outlines the research methodology; Section 5 presents the results and findings of the research work; and Section 6 is conclusion.

\section{Importance of Traditional Water Bodies}

Wetlands (including traditional water bodies) play a very important role in offering a wide range of services that are intrinsically linked to unhindered and facile functioning of life-sustaining activities on earth.

\subsection{Economic Services}

Significant contribution of tourism and fish production to India's GDP and employment can primarily be attributed to these water bodies and among these also, inland water bodies substantially helped in increasing the fish production from 0.2 million tons in 1950-1951 to about 5.1 million tons in 2010-2011 [9].

\subsection{Carbon Sequestration}

According to a study, wetlands approximately contain about $35 \%$ of global terrestrial carbon. Another study defines wetlands as the largest sinks of carbon compared to any other soil ecosystems. Very intensive anthropogenic or abiotic activities and global warming have significantly reduced their ability and proficiency to capture more carbon [10] [11]. 


\subsection{Pollution Abatement}

Wetlands acts as a filter for water which may contain pollutants, sediments, pathogens etc. However, the efficiency of the wetland to purify water depends on the loading rate. Loading into the wetland beyond a sustainable limit may cause deterioration of the wetland health and further impact nutrient cycling [12].

\subsection{Flood Control}

Role of wetlands in lessening the impacts of flood has been quite closely observed in various parts of the world. For example, in a study carried out for the assessment of flood control services of the Mississippi river basin, it was revealed that restoring the flood zone of the Upper Mississippi five-state watershed can potentially store 39 million acre-feet of floodwater, the volume that caused the Great Flood of 1993, and accounted for $\$ 16$ billion as a replacement cost for projected flood damage costs [13].

\subsection{Biodiversity Hotspots}

Wetlands, needless to mention strongly, are one of the most common habitats for different species of living organisms. They are important breeding areas of wildlife and provide a refuge for migratory birds. Some wetlands are also home to endangered and threatened animal species [14].

\subsection{Recreational Services}

The recreational opportunities emanating from these wetlands include undertaking activities like hiking, boating, hunting, fishing, trapping and bird watching. It has also been noted that photography of wetland dependent birds alone allure around 50 million people worldwide to spend approximately $\$ 10$ billion each year [15].

\subsection{Life Sustaining Services}

It is a well-known fact that wetlands act as a lifeline for almost all living creatures/or organisms on earth [16].

\subsection{Groundwater Recharge}

Besides serving as a repository of water, wetlands are also helpful in recharging the groundwater with the recharge rate being primarily dependent on soil, vegetation, site, perimeter to volume ratio, and water table gradient [17].

While, no flourishing human civilization can conceivably lose sight of the essentially important functionalities associated with these wetlands, the rising challenges have repeatedly featured as environmental concerns of significant gravity. The next section discusses the extent of wetlands in India and the reasons behind decreasing wetland area. 


\section{Areal Extent of Wetlands in India and Major Reasons of Degradation}

In India, results obtained from various inventories, especially National Wetland Atlas prepared by Space Application Centre (SAC) and Indian Space Research Organization in 2011 showed that the country is home to about 757,060 wetlands occupying an area of 15.3 million hectare and accounting for approximately $4.7 \%$ of the total geographical area of the country. Out of these, the relative proportion of each of the different types of wetlands is $69 \%, 27 \%$, and $4 \%$ for inland wetlands, coastal wetlands and other wetlands respectively.

While studies related to the loss of wetlands in India have been carried out only to a diminutive extent, a survey Wildlife Institute of India survey reveals that the country has lost $70 \%-80 \%$ of individual fresh water marshes and lakes in the Gangetic flood plains (Figure 1).

The literature review suggests following reasons, with examples from India, for the degradation of quality and quantity of the water bodies.

\subsection{Urbanization}

Increasing built up area is damaging the catchment hydrology and in some cases the construction is being done on the wetland itself. For example, Charkop Lake in Maharashtra, Ousteri Lake in Puducherry, Deepor beel in Guwahati are well known examples of encroachment. Another interesting example of encroachment

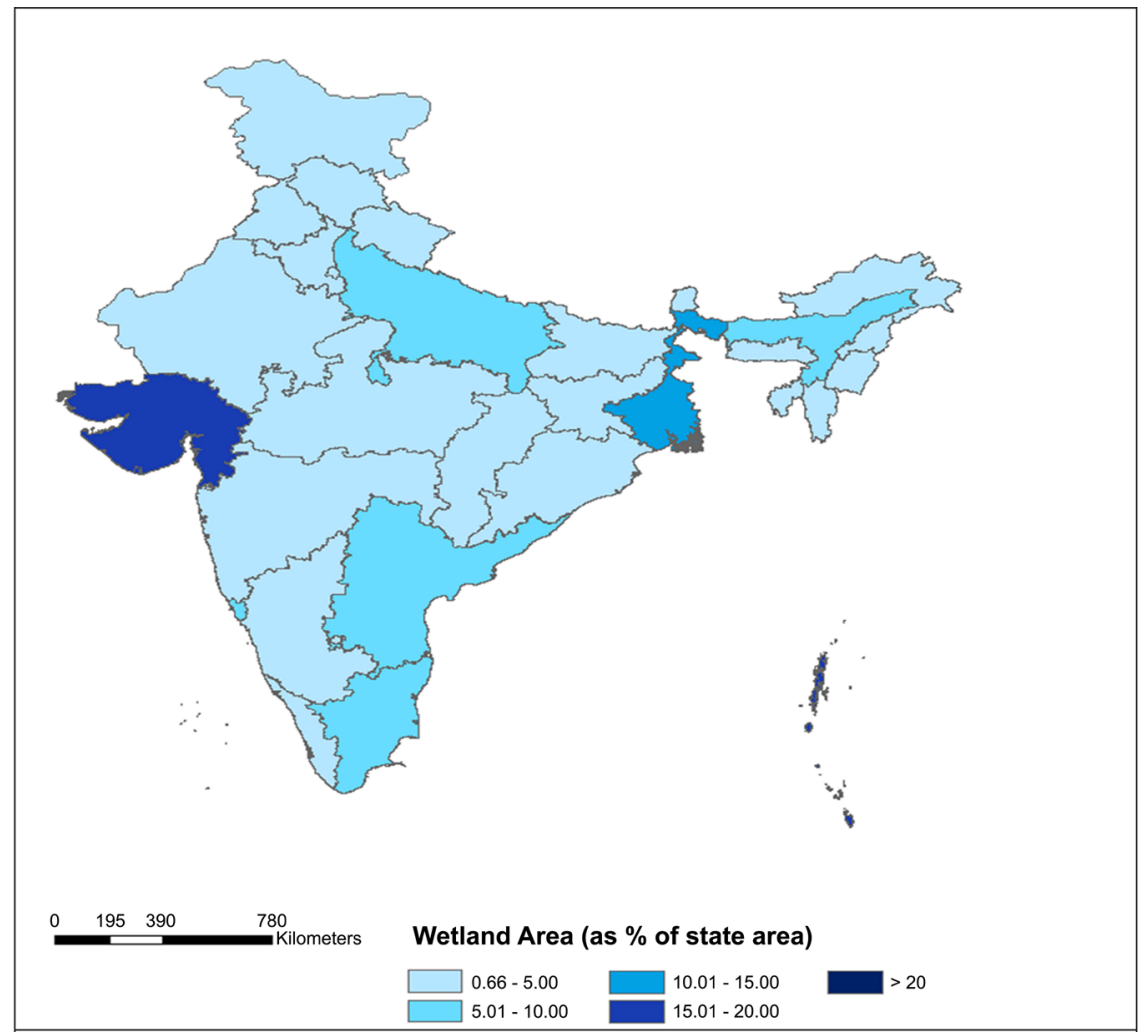

Figure 1. Map showing proportion of wetland area state-wise. Map Credit: Authors (Data credit: NWIA, MoE \& F). 
and pollution, not by some private builder but the government itself is Pallikaranai marshland in Bangalore [18]. Looking into the growth pattern in India, one could clearly see that India is urbanizing at a fast pace, an analysis of census data 2011 suggests that urbanization has increased at the rate of $31.8 \%$ in the last decade, which is a serious challenge to be managed [19]. Also, urbanization has been reported as one of the most significant factors contributing towards degradation and extinction of these wetlands [20].

\subsection{Industrialization}

Industrial activities discharge huge amounts of untreated effluents and toxic chemicals directly into the water bodies. Such activities have converted various wetlands into a waste disposal site across the county. Himayatsagar and Osmansager lakes in Hyderabad, which were once used for as a source of drinking water are now filled with toxic effluents discharged by the industries located nearby [21].

\subsection{Chemical Intensive Agriculture}

Farming practices, including use of fertilizers rich in nitrogen and phosphorous, and their run-off causes eutrophication in water bodies. For example, Lonar Lake, situated in the Buldhana district of Maharashtra, which has been identified as the third largest natural salt water lake in the world is the victim of cultural eutrophication due to the accumulation of toxic chemicals like inorganic fertilizers, pesticides, and insecticides coming along the runoff [22].

\subsection{Degradation of the Catchment}

Removal of vegetation from the catchment area leads to high run-off and pollution of wetlands. Chandigarh once experienced this problem of heavy siltation due the removal of vegetation in the watershed [23].

\subsection{Illegal Mining Activities}

Illegal mining is done for building material such as sand and stones both on the catchment and on the bed of the lake have extremely damaging impact on the waterbody. The Basam and Lake in Jodhpur, once the only source of drinking water for the city of Jodhpur, has been suffering from illegal mining for the more than two decades despite the court's order to stop mining in 1999. Surajkund Lake in Haryana is another example of illegal mining activities that have destroyed the lake [20].

\subsection{Unplanned Tourism Activities}

Tourism activities without systematic regulation has become a common threat in recent years and has contributed to the degradation of many water bodies especially at the high altitude lakes, for examples, Dal Lake in Srinagar, Tso Morari and Pongsho Lakes in Ladakh [24]. 


\subsection{Cultural Misuse}

Practices such as immersion of idols, throwing of non-biodegradable materials, made up of metals and painted with synthetic paints containing some heavy metals, which causes serious metallic pollution in the water body. These practices are common across India [25].

\section{Methodology}

Site Selection and details: Meerut District is known for its historical importance as it has many sites that can be traced back to the Epic Mahabharata period. It is located in the western part of Uttar Pradesh situated between $28.740 \mathrm{~N}$ and 29.270 N latitudes and 77.440 and 78.140 E longitudes. It has an area more than $2500 \mathrm{~km}^{2}$ [26], majorly dominated by agriculture land use (Figure 2).

It is bounded by Muzaffarnagar district is in the north, Ghaziabad, Bulandsahar and Gautam Budh Nagar districts in the south, Bijnore and Jyotibaphule Nagar in the east and Baghpat in the west [27]. It has 3 tehsils and 12 blocks.

Naturally, Meerut is a water rich region as India's two major annual rivers Ganga and Yamuna forms the eastern and western borders of the district distinguishing it from the surrounding area. The land is very fertile and therefore agriculture has been the main occupation for people in the area. Due to urbanization and industrialization the water quality has severely declined leading to irrigation with poor quality water. As a result, many farmers are refusing to eat their own produce. There are numerous large scale and small scale industries in the city.

People in the area are now in a pitiful situation as they have made themselves

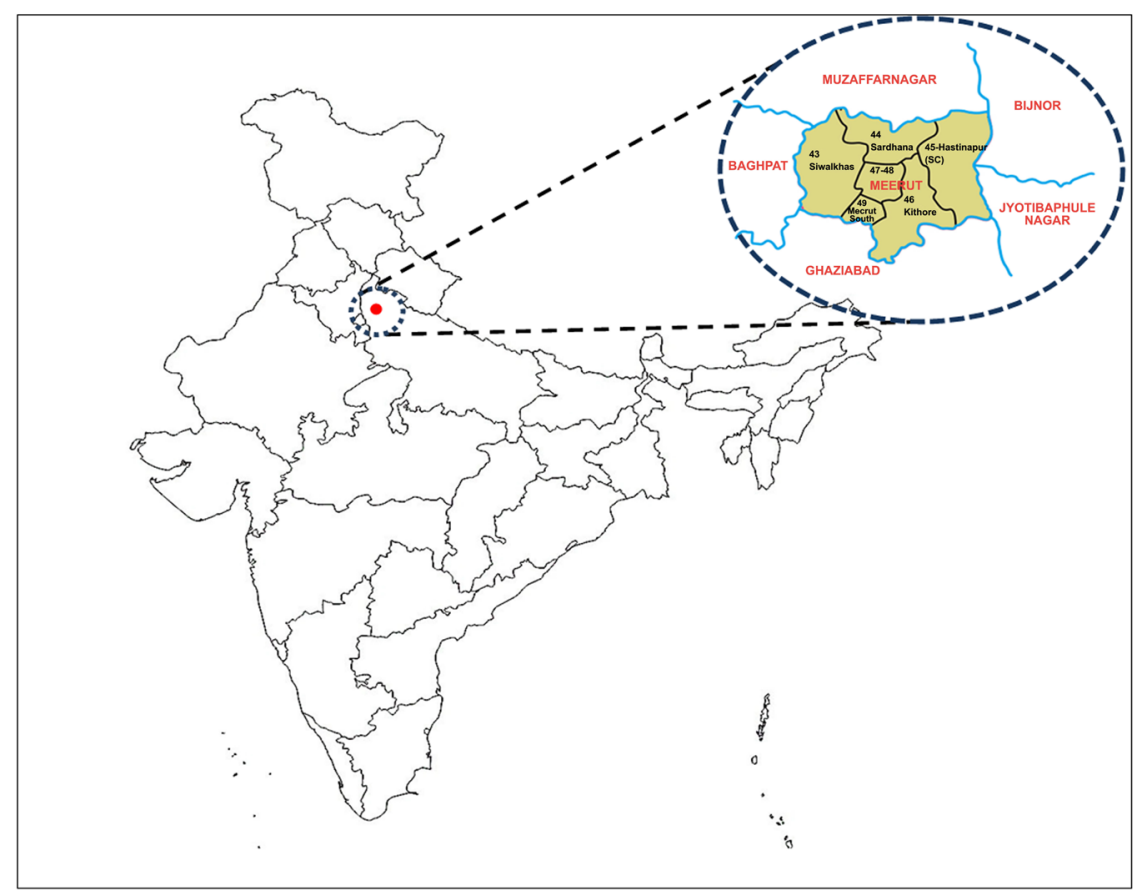

Figure 2. Map showing location of Meerut District. 
completely dependent on the centralized irrigation systems and groundwater, as there is hardly any community level initiative focused around managing water in a decentralized way. This is not the case with Meerut only but this situation could be easily related to any tier I and tier II cities and also places where growth has taken at a fast pace without considering the carrying capacity of environment.

In revenue department records, around 3000 water bodies are registered however when NEER foundation, a NGO in Meerut, did the survey of the ponds only 1944 ponds were found present and 715 amongst them were in permanent dry state (see Figure 3 ). This clearly shows that more than 1000 ponds have vanished and there are many at verge of getting extinct.

The existing ponds are suffering from different problems such as excessive water pollution, reduced capacity to store water, lesser groundwater recharge potential, loss of biodiversity, eutrophication etc.

The current management of these ponds is under the control of municipal bodies which are not giving sufficient attention to conservation and rejuvenation of these ponds.

\subsection{Sampling Methodology}

A total of 120 ponds were randomly selected. To get a true sense of pollution and state of these ponds, 10 ponds from each block were selected. Random function of Microsoft Excel was used to assign unique numbers to these ponds and then we arranged the ponds in the ascending order. The top 12 ponds that appeared in the list, for each block, were chosen for this study. There were few ponds, around thirteen, which were not easily accessible so the next pond in the list was selected in these cases.

The 120 ponds were tested for nine parameters using on-site water testing kits (Jal-Tara kits, certified by SGS laboratories) developed by Development Alternatives. Standard sampling procedure was followed to test following parameters: Temperature, pH, Hardness, Turbidity, Chloride, Nitrate, Phosphorus, Dissolved Oxygen, and Fecal Coliform. After every 3 samples, 1 blank sample (distilled

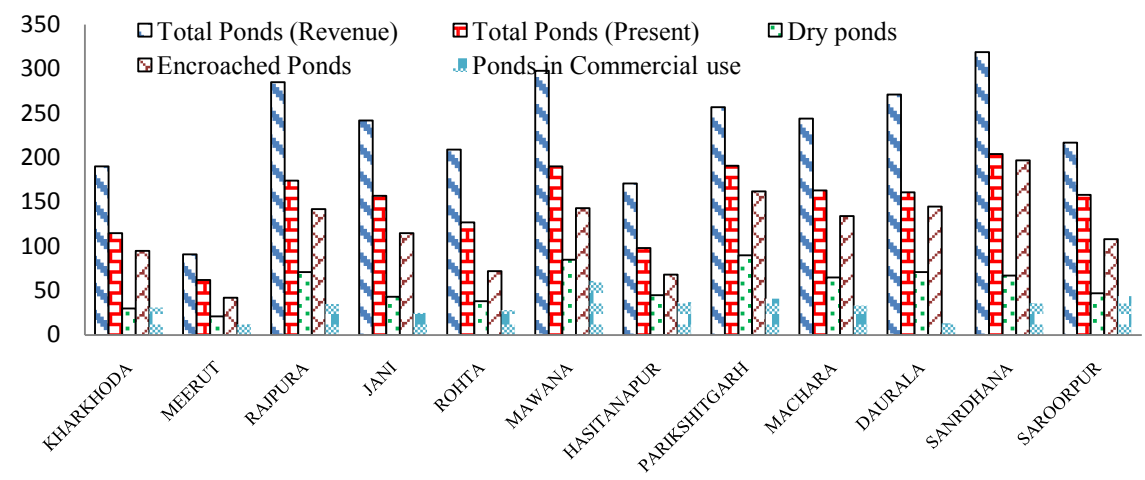

Figure 3. Block-wise status of ponds in Meerut district. Source: NEER Foundation Analysis. 
water) was used for calibration and after every 5 samples one replica was used for error assessment. Analyses of the data against BIS drinking water standards was done as these ponds were used for drinking purposes by animals and in some cases human as well.

Also, latitudinal and longitudinal coordinates of these ponds were taken using a GPS device. These points were then plotted on GIS platform and subsequently on Google Earth. An analysis of the change in the area of these ponds was done using imageries of the previous period depending on the quality of the imageries freely available. Most of the imageries used are of period 2005-2008. Therefore, nearly a decadal variation in area of these ponds was observed.

\subsection{Interview and Public Perception}

Informal discussions with village households residing nearby these ponds were conducted to understand the change in land use, modification in agricultural practices and change in the way these ponds are utilized. The discussion also captured issues such as community perception about the degrading status of these ponds, efforts taken up by the government and local agencies to rejuvenate them etc.

\section{Results and Findings}

\subsection{Temperature:}

Its Effects on the chemical and biological aspects of a water body are quite noteworthy as it intrinsically impacts other essential parameters. Temperature determines chemical processes such as solubility and reaction rates; biological process such as metabolism, growth, reproduction; Species composition; water density and stratification; dissolved oxygen concentration etc. Thus temperature is a very important parameter for determining water quality [28].

Results: Figure 4 shows the average temperature of ponds across the 12 blocks of Meerut District, which falls well within the survival range of tropical aquatic lives. It can be observed from the figure that, for most of the blocks the average temperature recorded was in the range of $18^{\circ} \mathrm{C}-21^{\circ} \mathrm{C}$, with only few ponds having temperature slightly above $21^{\circ} \mathrm{C}$ which could be attributed to difference in time of the day when the ponds were sampled. We didn't observe thermal pollution in any of the ponds studied.

\section{2. $\mathrm{pH}$}

It determines the acidic or basic nature of water. The $\mathrm{pH}$ range is $0-14$ with 0 being highly acidic and 14 highly alkaline. Both extreme conditions are unsuitable for sustaining most of the life forms. Since $\mathrm{pH}$ can be affected by chemicals in the water, $\mathrm{pH}$ is an important indicator of chemical pollution in water [29]. This parameter essentially determines the solubility of heavy metals in water, the concentration of $\mathrm{CO}_{2}$ and subsequently the rate of survival of aquatic life. The effect of high $\mathrm{pH}$ various from irritation in eyes, mucous membrane and 


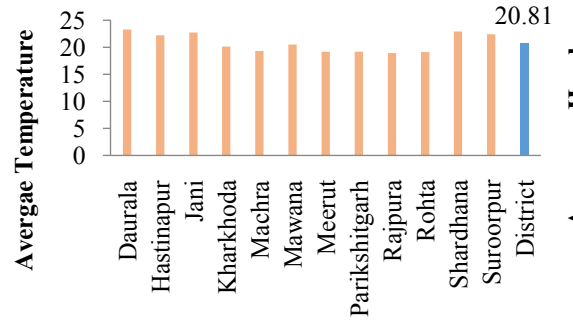

Blocks

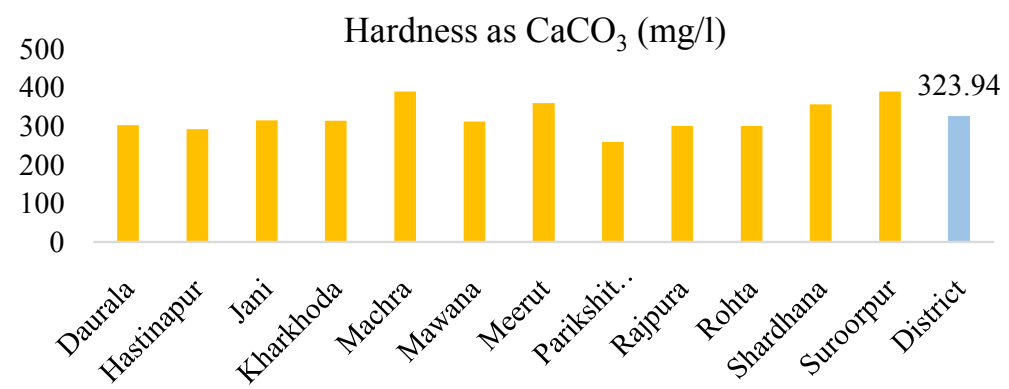

Figure 4. Temperature, $\mathrm{pH}$ and hardness levels of ponds, block-wise in Meerut district.

skin to gastrointestinal diseases. Bureau of Indian Standards (BIS) recommends water with a $\mathrm{pH}$ range of 6.5 to 8.5 for human consumption [30].

Results: In Meerut, $80 \%$ of the ponds sampled had $\mathrm{pH}$ in the range of $7-8$. Only $20 \%$ of the ponds had the $\mathrm{pH}$ values above 9 , with just two ponds having $\mathrm{pH}$ above 10. It would be important to mention that $70 \%$ of the ponds in Mawana block, which is known for sugar production, had $\mathrm{pH}$ above 9 (see Figure 4 above).

\subsection{Hardness}

Dissolved polyvalent cations, mainly Calcium and Magnesium, causes hardness in water and it is most commonly expressed as $\mathrm{CaCO}_{3} \mathrm{mg} / \mathrm{l}$, water. If the value is less than $60 \mathrm{mg} / \mathrm{l}$, then water is considered as soft. $100 \mathrm{mg} / \mathrm{l}$ is common in natural sources [30]. As such, hardness does not have any major impact on human health. It mitigates metals toxicity, because $\mathrm{Ca}^{2+}$ and $\mathrm{Mg}^{2+}$ prevents fish from absorbing metals such as lead, arsenic, and cadmium into their bloodstream through their gills [31].

BIS defines $600 \mathrm{mg} / \mathrm{l}$ as permissible limit and $200 \mathrm{mg} / \mathrm{l}$ as acceptable limit for total hardness $\left(\right.$ as $\left.\mathrm{CaCO}_{3}\right)$.

Results: Out of the 120 ponds sampled, 13 ponds (11\%) were having a value below $200 \mathrm{mg} / \mathrm{l}$, while 78 ponds (65\%) had hardness value between $200 \mathrm{mg} / \mathrm{l}$ to $400 \mathrm{mg} / \mathrm{l}$ and 28 ponds (23\%) had a value between $400 \mathrm{mg} / \mathrm{l}-600 \mathrm{mg} / / \mathrm{l}$. Only one pond in Manu village in Suroorpur block had total hardness value, above permissible limit, of $616 \mathrm{mg} / \mathrm{l}$ (see Figure 4).

\subsection{Nitrate}

A colorless, odorless, and tasteless compound which naturally occurs in soil. It is 
an integral part of the nitrogen cycle and plants use it to satisfy nutrient requirements. Break down of fertilizers, decaying plants, manures or other organic residues by microbes forms nitrate compounds. During rain it can get dissolved in water and enter the surface drinking water sources. Also, due to its high mobility it can leach into groundwater. Drinking water with high nitrate concentration may cause methemoglobinemia, an illness found especially in infants. The major sources of nitrate are fertilizers and manure, animal feedlots, municipal wastewater and sludge, septic systems, and $\mathrm{N}$-fixation from atmosphere by legumes, bacteria and lightning [32]. BIS has set a limit of Nitrate $\left(\right.$ as $\left.\mathrm{NO}_{3}\right)$ as 45 $\mathrm{mg} / \mathrm{l}$ with no relaxation for drinking water.

Results: Nitrate concentration in $48 \%$ of the ponds was below detectable limit, while $30 \%$ of the ponds showed nitrate concentration below $10 \mathrm{mg} / \mathrm{l}$ (Figure 5). In total $10 \%$ of the ponds had nitrate levels above the limit, with 2 ponds, one in Aetmadpur village, Machra block and one in Bhoop Garbi village, Jani block showing value above $100 \mathrm{mg} / \mathrm{l}$. Clearly, the ponds were receiving large volume of sewage and run-off from the nearby agriculture fields.

\subsection{Phosphorus}

It is an essential element and is required in sufficient quantity for crop growth. However, when the concentration of nitrogen and phosphorus increases in a water bodies it facilitates algal growth. When algal growth is excessive (eutrophication), it uses up Dissolved Oxygen, killing other vital aquatic species. The recommended maximum value of Phosphate in water is $0.1 \mathrm{mg} / \mathrm{l}$, above which the eutrophication accelerates [33]. Natural sources of phosphorus are rocks, groundwater etc., however major sources of phosphorus pollution are human induced such as agriculture inputs (fertilizers, animal dungs), wastewater, detergents etc.

Results: In ten blocks out (total 77) of the ponds showed phosphorus contamination above recommended level of $1 \mathrm{mg} / \mathrm{l}$. Nearly $20 \%$ of the sampled ponds had Phosphorus in the range of $0.5-1 \mathrm{mg} / \mathrm{l}$, while only 3 ponds had phosphorus below detectable limit (Figure 6). Kharkhoda and Parikshitgarh blocks had no

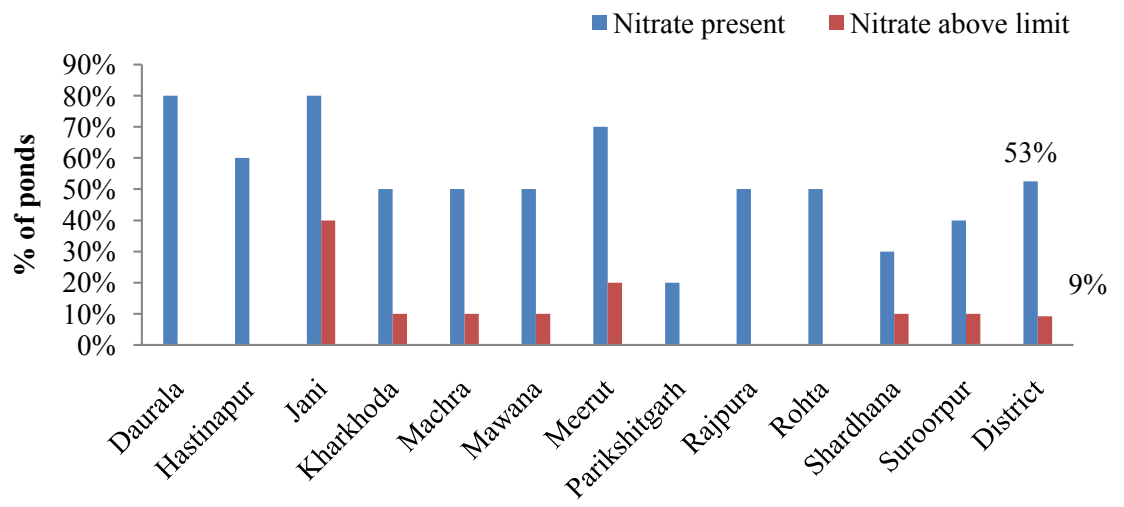

Figure 5. Percentage of ponds having nitrate and ponds having nitrate above prescribed limit, block-wise in Meerut district. 


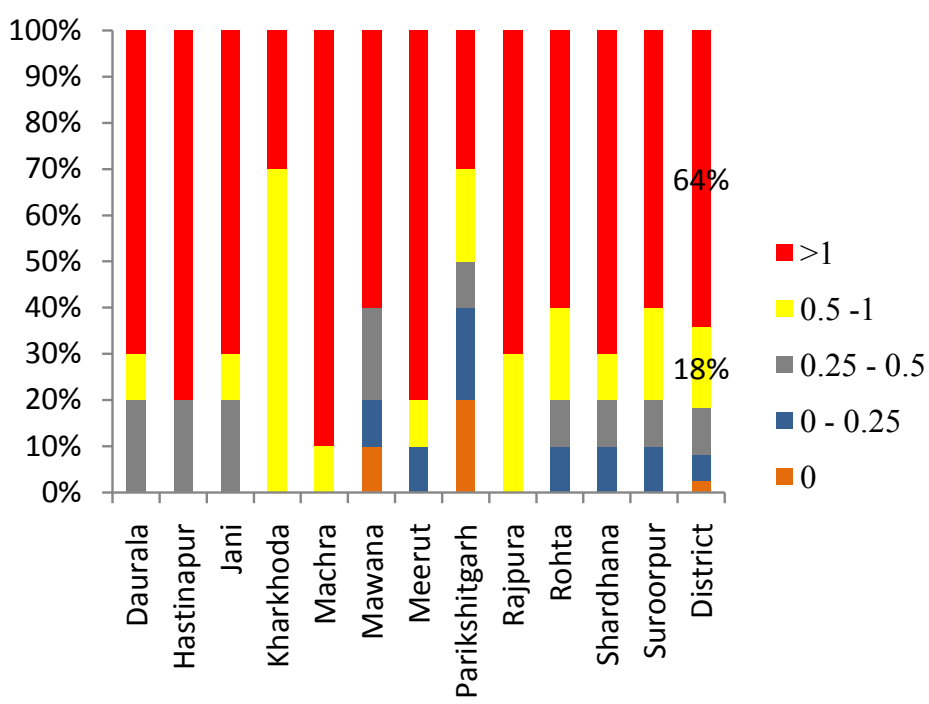

Figure 6. Block-wise classification of sampled ponds on the basis of level of Phosphorus present, Meerut district.

ponds having $\mathrm{P}$ contamination above the recommended limit, while in Machra block $90 \%$ of the ponds had P contamination above recommended limits. Eutrophication was found in most of the ponds (see Annexure 1) due to high level of Phosphorus and potential sources, as seen on the site, could be wastewater coming from the nearby areas.

\subsection{Fecal Coliform}

Presence of fecal coliform indicates strong possibility of sewage contamination. They are not harmful but their presence is a signal that water is contaminated with pathogenic (disease-causing) bacteria, viruses, and protozoans that also lives in human and animal digestive systems. Wastewater streams, on-site septic systems, domestic and animal manure, etc., are the major sources of fecal coliform. In addition to indicating presence of disease causing microbes, they can also cause cloudy water, unpleasant odors, and an increased oxygen demand. (EPA 2012) BIS recommends no presence of fecal coliforms in the drinking water.

Results: All the ponds tested for presence of fecal coliform showed positive results. For fecal coliform, 20 ponds, two in each block were tested due to the limited availability of reagents, and every pond showed presence of fecal coliform. Based on the investigation of on-ground situation and test results, wastewater drains coming from the nearby households seem to be the source of the fecal coliform in the water bodies.

\subsection{Turbidity}

It is a measure of clarity of water and its ability to allow light to pass through. Materials such as soil particles, algae, plankton etc., which forms the suspended materials in water, increases the turbidity of water. All these suspended particles 
cause haziness or cloudy water. It is measured in nephelometric turbidity units or NTUs. If turbidity is high, it leads to decrease in DO because the suspended particles absorb heat and increase the temperature of water and warm water can hold less oxygen. As amount of light that can pass through turbid water reduces, it has a negative impact on photosynthesis and thus the production of DO. Suspended materials can clog fish gills, reducing resistance to disease in fish, lowering growth rates, and affecting egg and larval development [34] (EPA 2012).

BIS recommends 1 NTU as the acceptable limit and 5 NTU as the permissible limit in absence of any alternate source for drinking water.

Results: More than half of the ponds had turbidity value above 100 NTU. While nearly $25 \%$ of the ponds had a value between 25 - 50 NTU, $17 \%$ had turbidity value between 50 - 100 NTU. Thus around $93 \%$ of the ponds sampled had turbidity above recommend limit of 5 NTU. Rest 7\% had a value in between 0 25 NTU. Block-wise distribution of these ponds on the basis of turbidity value has been represented in Figure 7. Seven blocks out of 12 had no ponds with a turbidity value less than 25 NTU.

\subsection{Chloride}

$\mathrm{Cl}$ - is a major anion found naturally in all waters. Its concentrations in natural waters can range from less than $1 \mathrm{mg} / \mathrm{l}$ in rainfall and some freshwater aquifers to greater than $100,000 \mathrm{mg} / \mathrm{l}$ for groundwater within deep intra-cratonic. Seawater has a $\mathrm{Cl}$ - concentration greater than $19,000 \mathrm{mg} / \mathrm{l}$. Although chloride is non-toxic, at higher concentration the taste of water becomes salty and is corrosive in nature. It also damages terrestrial and aquatic plants and aquatic animals at concentrations a slow as $210 \mathrm{mg} / \mathrm{l}$ [35]. BIS recommends $250 \mathrm{mg} / \mathrm{l}$ as the acceptable limit and $1000 \mathrm{mg} / \mathrm{l}$ chloride concentration as the permissible limit in absence of any alternate source for drinking water.

Results: In Meerut, chloride concentration in most of the ponds did not

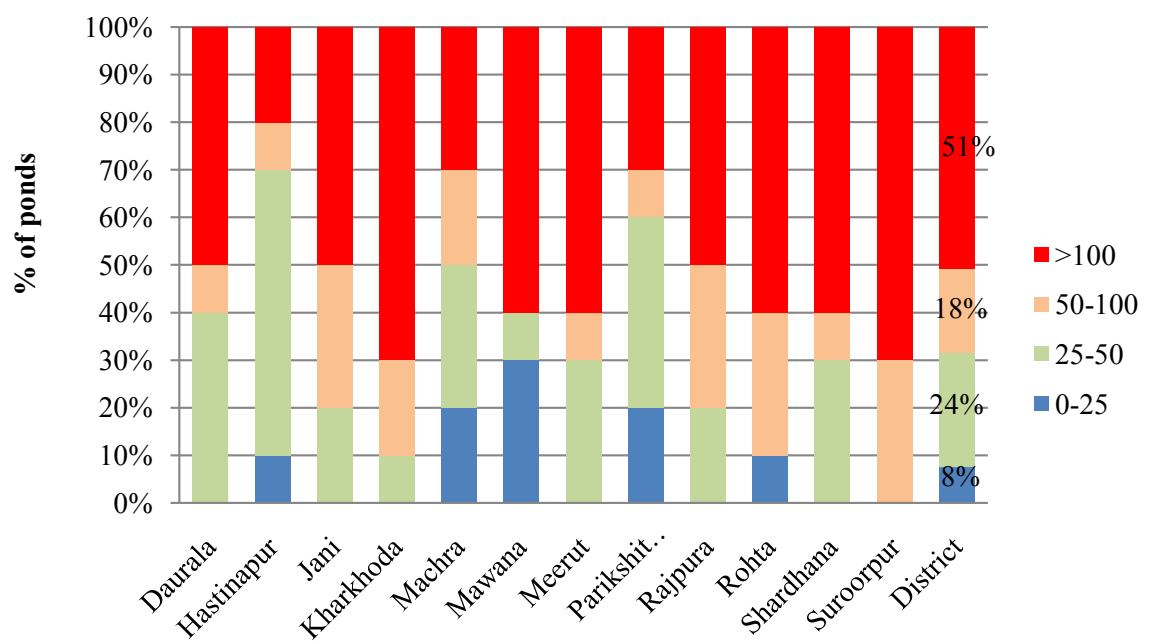

Figure 7. Block-wise classification of sampled ponds on the basis of value of turbidity, Meerut district. 
exceed $250 \mathrm{mg} / \mathrm{l}$ which is a good sign. The value of chloride concentration varied from around $56 \mathrm{mg} / \mathrm{l}$ to around $720 \mathrm{mg} / \mathrm{l}$. Around $17 \%$ of the ponds had chloride concentration above acceptable limit i.e. $250 \mathrm{mg} / \mathrm{l}$ but none crossed the permissible limit. Only two ponds in Machra block, one in Kayasth Bada and one in Dabathla village had a chloride concentration above $500 \mathrm{mg} / \mathrm{l}$. Such high values might impact certain organisms particularly during the metamorphosis stage [36].

\subsection{Dissolved Oxygen (D0)}

It is one of the most important components that determine the health of a water body. Dissolved oxygen concentration fluctuates inversely with temperature on a seasonal and daily basis. Thus DO increases in winter season and during night time. However, due to no photosynthesis, which is the major source of oxygen, at night the DO level does not increase too much [37].

DO levels below $5 \mathrm{mg} / \mathrm{l}$ puts aquatic life under stress and as oxygen levels fall below $1-2 \mathrm{mg} / \mathrm{l}$, there occurs large fish kills with the water body ultimately turning into a dead zone [38]. BIS recommends a value of $6 \mathrm{mg} / \mathrm{l}$ for drinking water sources.

Results: Of the 120 ponds tested in the Meerut district, $50 \%$ of the ponds had dissolved oxygen concentration below $5 \mathrm{mg} / \mathrm{l}$ which is a matter of serious concern. Amongst the blocks, the situation in Daurala block is worst as $90 \%$ of the ponds had DO level below $5 \mathrm{mg} / \mathrm{l}$ and an average DO level around $2 \mathrm{mg} / \mathrm{l}$ (Figure 7).

Ponds in Rohta block are in best condition as $90 \%$ of the ponds had DO level above $5 \mathrm{mg} / \mathrm{l}$. Commenting on one reading of DO about the health of the pond is not accurate as it would vary with season and day-time. However, we can do comparative analysis of the ponds as they have been tested in day time and in the same season. From the data collected and on-ground situation analysis, the algal growth and eutrophication in many ponds look like the major cause of low levels of dissolved oxygen (Figure 8).

\section{Spatial Analysis of Change in Area of These Water Bodies in the Last Decade}

At a district level, more than $50 \%$ of the ponds showed a decrease in the area. $10 \%$ of these ponds decreased in area by more than $40 \%$. However, majority of the ponds which showed less than $20 \%$ decrease in area (more than $80 \%$ ). Nearly $35 \%$ of the ponds showed an increase in area but increase in area is miniscule as again majority of them (more than 90\%) showed an increase below 30\%. If we compare total area increased vs decreased, then we can see a decrease in total area of the ponds by $66,106.57 \mathrm{~m}^{2}(7 \%)$. This analysis is limited to only one-decade variation and if we analyze change in area over say 25 - 30 years, we will see a drastic decrease in the area under these water bodies.

A block-wise comparison of the change in area of these ponds showed that 


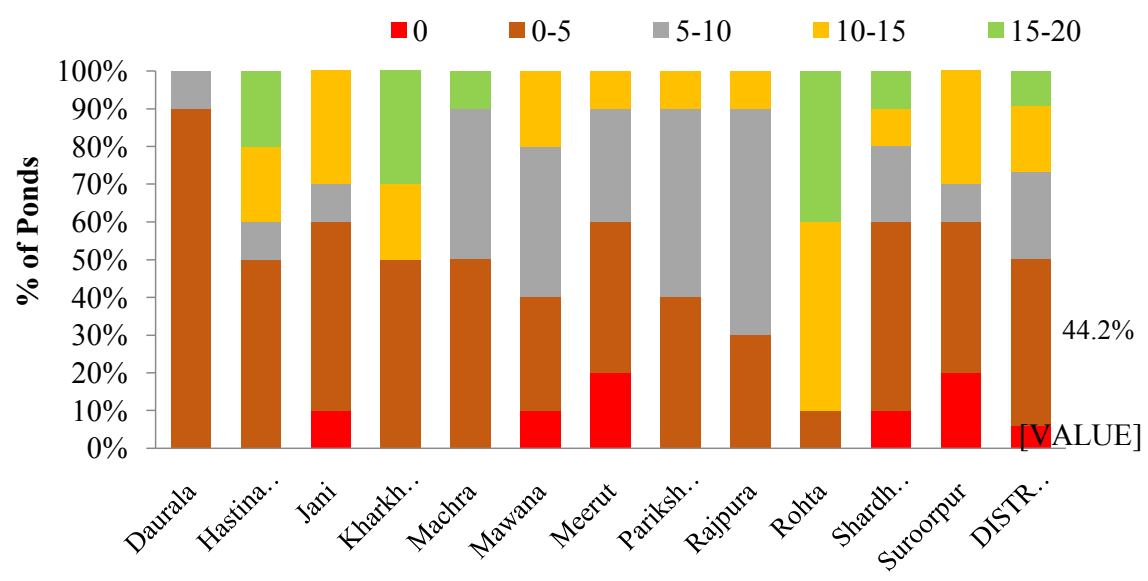

Figure 8. Block-wise classification of sampled ponds on the basis of value of DO (in $\mathrm{mg} / \mathrm{l})$, Meerut district.

except Jani, Kharkhoda and Mawana blocks, all the blocks showed a net decrease in total area of ponds. Ponds in Meerut block experienced maximum decrease in area (16.82\%), followed by Rajpura (15\%) and Suroorpur (12.3\%). Ponds in Rohta and Hastinapur blocks experienced the least change in area. Jani block experienced maximum increase in pond area $(9.45 \%)$, followed by Kharkhoda block (5\%) (Figure 9).

\section{Discussion}

During interaction with community members, the senior citizens were the one really concerned as they have seen these water bodies in a much better state. They said that some of these ponds were built by their forefathers and it is really painful to see them dying lying like this. Also, other members of community have started becoming concerned as their children are getting due to increased pollution levels. However, community's expectation is that government would do all the rejuvenation work. This attitude has to change if the pollution has to be controlled at source. People across the district were seen preparing huge piles of cow/buffalo dung briquettes to be used as fuel and fertilizer. These piles are however kept for sun drying very close to the ponds and whenever these piles exceed in number or are not put into use, the manure is funneled into the water bodies.

As the results highlight, $100 \%$ of ponds have fecal contamination which is in agreement to the previous research work stating conversion of these water bodies into sewage ponds. Lack of sewage treatment facilities and direct run-off from the nearby fields could be seen everywhere. As several researchers stated, there is encroachment happening on the water bodies in other parts of the country, similar practices were seen in Meerut district. In some cases, there was direct encroachment on the storage area and in other cases the channels carrying water to the ponds were encroached upon. In addition to the sewage and agriculture run-off flowing directly to these ponds, unabated dumping of solid waste 


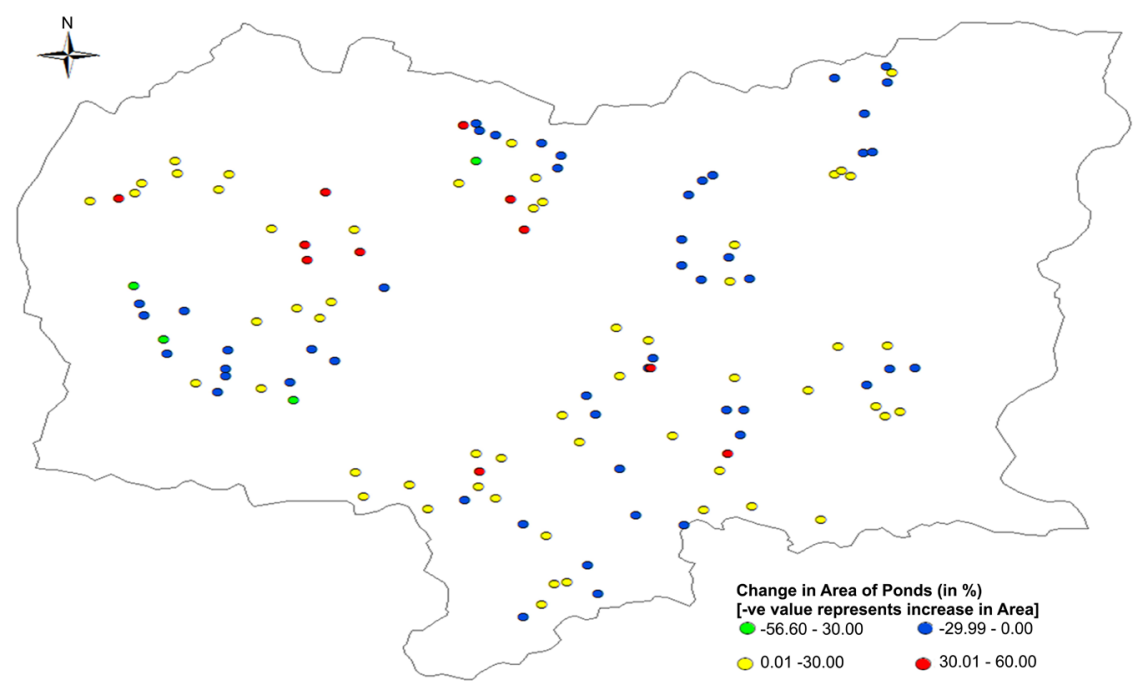

Figure 9. A map showing decadal change in area (2005-2007) of 120 ponds distributed across the Meerut district (ponds represented as dots).

into the pond waters have resulted in poor and continuously degrading aesthetics and quality of most ponds. This has also resulted in decrease in water storage capacity of these ponds. Eutrophication due to nutrient pollution could be seen almost everywhere, only the ponds on private lands or remote areas are in a better state. Meerut being an industrially prominent area is also having problem of the effluent, generated from sugar mills and others, ending up in certain ponds which receives water only during those 120 - 200 days in a year when these mills are functional. This is the cause of high T.D.S and low D.O. in these ponds. Most inhabitants complained of the government paying very little to absolutely no attention towards improving the condition of these ponds. With inadequate supply of funds, poor environmental awareness, lack of treatment facilities, high agriculture run-off and absolutely no strong protection and managerial strategies adopted for their revival, these entities remain almost lifeless.

The current management of these ponds in under the control of municipal department, which is under staffed and is fire-fighting with daily demands issues. Same is the case with various districts across the country. There should be dedicated wing and staff to monitor and conserve these water bodies, which not only provide essential services but also provide resilience against climate change impacts. Most of the recent studies are advocating for water sensitive urban designing, traditional water bodies form an integral part of such planning strategies.

The limitations of this study are that we have not been able to capture temporal variation in the water quality of these ponds and could not test BOD and COD, this is due to non-availability of historical water quality data of any of these ponds and limited resources, respectively. The limitation of absence of historical water quality data holds true for majority of the traditional water bodies across India. Also, further research on analysis heavy metal contamination could be done in this area. 


\section{Conclusions}

Some serious steps are required to be taken to preserve these dying traditional water bodies as this is not happening in Meerut only but across India. Indian government should on priority start: mapping the small water bodies on GIS platform, monitoring the water quality, penalizing the defaulters, and putting high values on these water bodies, and give proper weightage to their protection. Generating awareness for bringing in behavior change should be the core of the conservation plan.

In US, during development phase in 1980s, as wetlands were degrading, the National Wetland Policy Forum recommended "no net loss" policy under which proposed development plans must avoid, minimize and if necessary provide compensation for unavoidable wetland loss [39]. Such regulations should be adopted at a watershed level with long term water stewardship plans and effective legal and financial assurances for long-term site sustainability and monitoring [40]. In India also a similar stringent regulation should be put into action without further delay.

That said, only government would be unable to protect these water bodies without local support. NGOs could play a great role in making people aware, especially the young generation, about the importance of these water bodies. Thus, collective effort should be directed towards making people understand the long term benefits of conserving and managing these water bodies.

\section{Acknowledgements}

We would like to express our gratitude towards Dr Arunabha Ghosh for keeping faith in us and supporting our work. We are grateful to Dr Chaturvedi for reviewing the paper and suggesting crucial modifications. This work would not have been possible without the on-field support provided by Raman Kant and NEER Foundation.

\section{References}

[1] Ministry of Environment and Forests (2007) Conservation of Wetlands in India.

[2] SAC and ISRO (2011) National Wetland Inventory \& Assessment. Ministry of Environment \& Forests, Govt. of India, New Delhi.

[3] Nandy, S. (2012) Urbanisation and Resultant Depletion of Water Bodies in Tollygunge Ward, Kolkata Municipal Corporation: 1935-2010. Indian Cartographer, 343-376.

[4] Bassi, N., Kumar, D., Sharma, A. and Pardha-Saradhi, P. (2014) Status of Wetlands in India: A Review of Extent, Ecosystem Benefits, Threats and Management Strategies. Journal of Hydrology: Regional Studies, 2, 1-19. https://doi.org/10.1016/j.ejrh.2014.07.001

[5] Kurup, D.G. (2009) Are Villages Becoming the City's Dump Yards? The Hindu.

[6] Kang, A. and Seth, B.L. (2012) Black Curse of the Kali River. Down to Earth.

[7] Sajjad, H., Rashid, S.M., Prasad, S. and Suddin, R. (2013) Assessment of Groundwater Quality in Meerut City, India. International Journal of Environmental Protec- 
tion, 20-26.

[8] Ali, M. (2014) PMO Seeks Probe into Deaths Caused by River Pollution in U.P. The Hindu.

[9] Department of Animal Husbandry, Dairying \& Fisheries (2012) Annual Report 2011-2012. Ministry of Agriculture, Government of India, New Delhi.

[10] Wang, Y.C. and Yang (2004) Dynamics of Carbon Sequestration in a Coastal Wetland Using Radiocarbon Measurements. Department of Geological Sciences, Florida State University, Tallahassee.

[11] Department of Sustainability, Environment, Water, Population and Communities (2012) Issues Paper: The Role of Wetlands in the Carbon Cycle. Department of Sustainability, Environment, Water, Population and Communities, Australian Government, Canberra.

[12] Ministry of Natural Resources, Ontario, Canada (2015) Why Are Wetlands Important? Ministry of Natural Resources, Ontario.

[13] EPA (2006) Wetlands: Protecting Life and Property from Flooding. http://water.epa.gov/type/wetlands/outreach/upload/Flooding.pdf

[14] Sahu, R.K. (2015) Mega Biodiversity of India. Ahmedabad.

[15] Watershed Management Division, Vermont Department of Environmental Conservation (2015) Wetlands-Recreational Values and Economic Benefits. Montpelier.

[16] Silvius, M.J., Oneka, M. and Verhagen, A. (2000) Wetlands: Lifeline for People at the Edge. Physics and Chemistry of the Earth, Part B: Hydrology, Oceans and Atmosphere, 25, 645-652. https://doi.org/10.1016/S1464-1909(00)00079-4

[17] Virginia, C. (1986) An Overview of the Hydrologic Concerns Related to Wetlands in the United States. Canadian Journal of Botany, 64, 364-374. https://doi.org/10.1139/b86-053

[18] Kang, A. (2014) Protection and Management of Urban Lakes in India. CSE, New Delhi.

[19] Bhagat, R.B. (2011) Emerging Pattern of Urbanisation in India. Economic \& Political Weekly, 46, 10-12.

[20] Kang, A. (2013) Protection and Management of Urban Lakes in India. CSE, New Delhi.

[21] Ramachandraiah, C. and Prasad, S. (2004) Impact of Urban Growth on Water Bodies: The Case of Hyderabad, India. Centre for Economic and Social Studies, Hyderabad.

[22] Yannawar, V.B. and Bhosle, A.B. (2013) Cultural Eutrophication of Lonar Lake, Maharashtra, India. ISSR.

[23] Ilangovan, R. (2008) Restoration of Polluted Lakes: A New Approach. Water Resources Organisation, Chennai.

[24] Reddy, M.S. and Char, N.V.V. (2004) Management of Lakes in India. Ministry of Water Resources, Government of India, New Delhi.

[25] Kang, A. (2013) Briefing Paper: Legal, Institutional and Technical Framework for Lake/Wetland Protection. Centre for Science and Environment, New Delhi.

[26] Government of India (2011) Census. Government of India.

[27] MSME Development Institute (2013) Brief Industrial Profile of District Meerut. Ministry of Micro, Small \& Medium Enterprises, Govt. of India, Agra.

[28] Region Aquatics Monitoring Program (2015) Water Quality Indicators: Temperature and Dissolved Oxygen. 
http://www.ramp-alberta.org/river/water+sediment+quality/chemical/temperature +and+dissolved+oxygen.aspx

[29] The USGS Water Science School. The USGS Water Science School. http://water.usgs.gov/edu/ph.html

[30] World Health Organisation (2003) Hardness in Drinking-Water, Background Document for Development of WHO Guidelines for Drinking-Water Quality. WHO, Geneva.

[31] Murphy, S. (2007) General Information on Hardness. http://bcn.boulder.co.us/basin/data/NEW/info/Hard.html

[32] Self, J.R. and Waskom, R.M. (2013) Nitrates in Drinking Water. http://www.ext.colostate.edu/pubs/crops/00517.html

[33] Oram, B. Phosphates in the Environment. http://www.water-research.net/index.php/phosphates

[34] Minnesto Pollution Control Agency (2008) Turbidity: Description, Impact on Water Quality, Sources, Measures. Minnesto Pollution Control Agency, St. Paul.

[35] Walton, S.V.P.K. and Kelly, H.R. (2012) The Sources, Distribution, and Trends of Chloride in the Waters of Illinois. University of Illinois at Urbana-Champaign, Champaign.

[36] Molly Hunt, E.H. (2012) Chlorides in Fresh Water. Watershed Watch, 1-4.

[37] USGS (2016) Water Properties: Dissolved Oxygen. http://water.usgs.gov/edu/dissolvedoxygen.html

[38] Kemker, C. (2013) Dissolved Oxygen: Fundamentals of Environmental Measurements.

http://www.fondriest.com/environmental-measurements/parameters/water-quality/ dissolved-oxygen/

[39] EPA (2016) Wetlands Compensatory Mitigation.

[40] Gardner, R.C., Zedler, J., Redmond, A., Turne, R.E., Johnston, C.A., Alvarez, V.R., Simenstad, C.A., Prestegaard, K.L. and Mitsch, W.J. (2009) Compensating for Wetland Losses under the Clean Water Act (Redux): Evaluating the Federal Compensatory Mitigation Regulation. 


\section{Annexure}

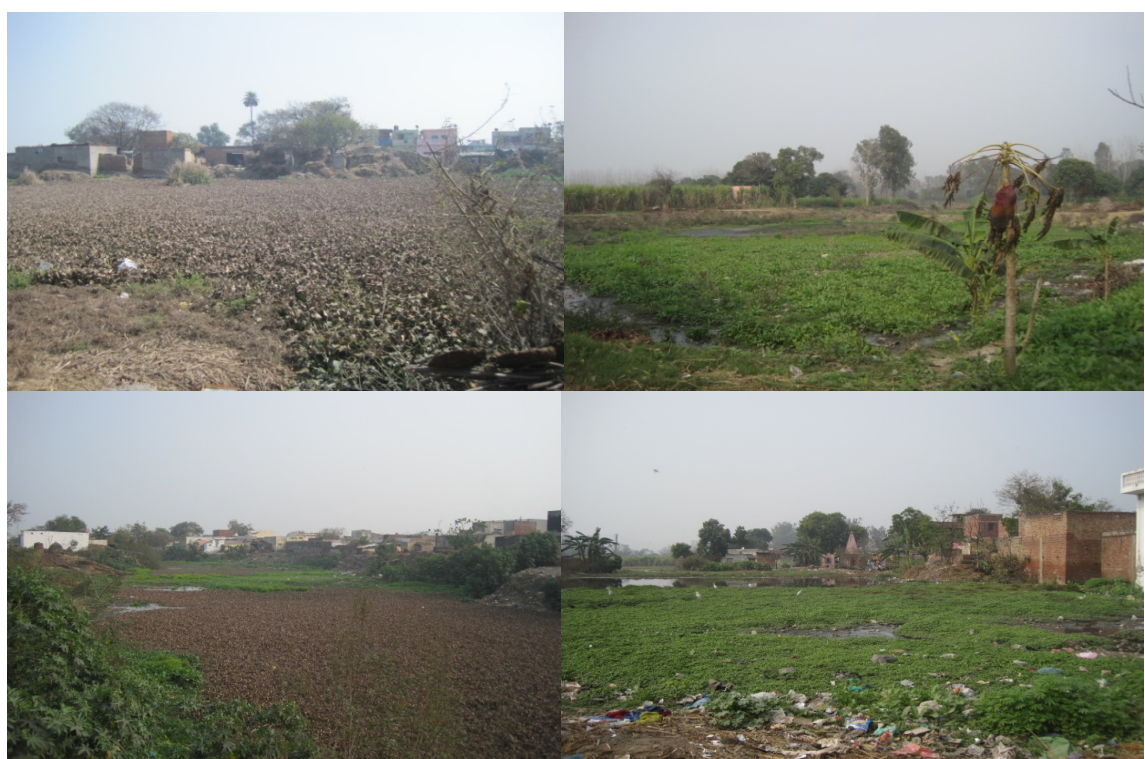

Annexure 1. Pictures of some ponds showing growth of vegetation due to nutrient contamination across Meerut district. Photo Credit: CEEW. 